\title{
Foreign Aid, Political Institutions and Economic Freedom: Empirical Evidence from Selected Developing Countries
}

\author{
Miraj ul Haq ${ }^{*}$, Nuzhat Shamim ${ }^{* *}$ and Muhammad Luqman ${ }^{* * *}$
}

\begin{abstract}
This article empirically examines the effects of foreign aid on economic freedom while considering the mediating role of political institutions. We contribute to the literature in two ways. First, we provide an empirical analysis of how different types of foreign aid affect the economic freedom of the receiving country. Second, we provide evidence regarding how political institutions mediate the foreign aid/economic freedom relationship. We use IV and GMM techniques to test a model using data from 40 developing countries covering the time period 1985 to 2016. Our analysis yields three main findings. First, democratic and politically stable countries enjoy more economic freedom. Second, foreign aid's net effect is to reduce economic freedom, whether we consider official development assistance (ODA) or net official assistance (NOA). Finally, economic freedom increases with both types of foreign aid if the receiving country's political institutions are more democratic and/or durable.
\end{abstract}

Keywords: Foreign aid, economic freedom, political institutions, panel data.

JEL Classification: F35, P48, D02, C23.

\section{Introduction}

The assessment of the impacts of foreign aid is well-covered in the development economics literature. Early empirical insights based on the dual gap model of Chenery and Strout (1966) focused on the aggregate macroeconomic effects of foreign aid. Further literature explored the

\footnotetext{
${ }^{*}$ Assistant Professor, International Institute of Islamic Economics (IIIE), International Islamic University Islamabad, E.mail: haqmirajeco@gmail.com

** M.Phil Scholar, International Institute of Islamic Economics (IIIE), International Islamic University Islamabad, E.mail: ns.ec0002@gmail.com

*** Lecturer, Kashmir Institute of Economics, University of Azad Jammu \& Kashmir, Muzaffarabad. Email: luqman.khan@ajku.edu.pk
} 
impact of foreign aid on economic growth, with findings ranging from foreign aid being growth-promoting to aid having significant negative impacts. However, the effects of foreign aid are manifold in nature, covering economic, political, and social aspects that go beyond simple macroeconomics. Consequently, recent work on the effects of foreign aid look at a myriad of issues ranging from macroeconomic structure and debt management prevailing in the 1980s to major events such as natural calamities or major public health events such as the HIV/AIDS crisis in the 1990s. Since the 2000s, most foreign assistance programs are developed to address various objectives simultaneously.

Economic freedom, according to classical economic thought, stems from the existence of free markets, free trade, and protection of property rights, intended not only to enhance the growth process but to increase individual choice set. ${ }^{1}$ Smith (1776) described a structure of natural liberty in which every individual maintains the utmost liberty that is compatible with economic freedom. The main promises of Smith's ideology were to permit laissez-faire free trade, low state spending, low taxes, and a negligibly interfering regime. Friedman (1962) defined economic freedom as "a system of free markets and private ownership that operates with limited interference from the government" and argued that economic freedom is a significant component of total freedom. Economic freedom is a precondition for political freedom, and Friedman suggests that economic organizations providing economic freedom (e.g. competitive capitalism), endorse political power by separating economic power from political power. He argued that capitalism, which is economic freedom, is a necessary condition for political freedom; however, the relationship between the two is composite and not unilateral.

Economic freedom is not only vital for the growth development, it also uplifts the social and political fabric of a country. Under economic freedom, individuals make economic decisions for themselves, motivating them to make optimal decisions, which is important for the growth and development of a country. From a social point of view, economic freedom provides personal autonomy, human dignity, and

\footnotetext{
${ }^{1}$ The classical liberal thought based on Smith (1776) idea "that institutions let the right of individuals to chase their own economic wellbeing will end in the prosperity of the entire humanity".
} 
power of self-direction. And as Friedman (1962) argued, from a political point of view, economic freedom is a precondition for political freedom.

Despite a burgeoning literature, empirical proof of a positive effect of foreign aid on economic freedom has not reached a consensus. Studies on the positive impact of foreign aid on economic freedom generally highlight the expansion of public investment and tax reduction (Vasquez, 1998; Dreher \& Gehring, 2012). Those studies that cast doubt on the positive impact of foreign aid on economic freedom emphasize rentseeking in aid receiving countries (Svensson, 2000; Dreher et al., 2015; Heckleman and Knack, 2009; Powell and Rayan, 2006). Svensson (2000), for example, suggested that receiving aid can destroy the quality of safety regulations by encouraging rent-seeking and corruption that in turn slow down the process of economic freedom in the receiving country.

The inconclusiveness in the literature on the subject is the first motive to take on this study. The second motive is to capture the impact of governance-related conditions that both the donor organizations (UN, IMF, World Bank) and donating nations started requiring in early the 1990s in order to make ensure the best utilization of foreign aid. Hence, the extent to which a country can benefit from foreign aid in the form of economic freedom is believed to be sensitive to the structure of political institutions in a particular country.

Keeping in view the mediating role of institutions in the foreign aid - economic freedom nexus, we hypothesize that the development of political institutions, a democratic regime, and continuity in political processes (durability) should mitigate the negative impact of foreign aid on the economic freedom of the receiving countries. Thus, we attempt to assess the impact of foreign aid on a receiving country's economic freedom conditional on the structure of its political institutions. Unlike existing explorations on the subject, our contribution is that we take into account separately the two different types of foreign aid, that are official development assistance (ODA) and net official assistance (NOA). Moreover, we provide evidence on the role a country's political institutions play in the foreign aid -economic freedom relationship.

We study 40 developing countries for the time period of 1985 to 2016. Three motives limit our analysis to a sample of 40 countries only. 
First, we focus on countries whose economies heavily depend on external sources including foreign aid. Second, the sample countries share some common characteristics: large governments, highly regulated monetary and exchange rate policies, and lack of legal structures and security of private property. Finally, most of the sample countries are passing through a transitional period of their political systems.

The rest of the study is organized as follows. Sections 2 presents a review of the related studies on the subject. Section 3 discusses our methodology which includes a discussion of the empirical model, definition and construction of variables, sample and sample selection criteria, and estimation methodology. Section 4 discusses our results. Finally, section 5 offers some conclusions.

\section{Insights from the Literature}

Since the late 1940s with the advent of the Marshall Plan, international economic collaboration has attempted to enhance the growth and development process. Mainly, three dimensions have been covered in related literature on foreign aid; that is, its effects, distribution, and driving factors. As far as the effects of foreign aid are concerned, the empirical insights mostly based on the dual gap model of Chenery and Strout (1966), which underlines the aggregate macroeconomic effects of foreign aid.

Studies promoting the positive impact of foreign aid on macroeconomic aggregates generally explain aid's impact as filling the dual gaps facing the recipient countries (Papanek, 1973; Bacha, 1990; Taylor, 1994; Islam, 1992; Thirlwall, 1999). These studies also point out that, without foreign aid, the fiscal gap limits the capacity of the public sector to invest in the infrastructure required for long-run growth and development. Moreover, foreign aid improves the growth capacity of receiving countries by filling of savings-investment gap.

Others argue that the positive effects of aid on economic growth are conditional on the receiving country's economic policies. Burnside and Dollar (2000) analyze the relationship between aid, policy, and economic growth using a data set of 56 developing countries and find that aid proves 
beneficial for economic growth in those countries maintaining good fiscal, monetary, and trade policies.

On the other hand, a number of studies cast doubt on the macroeconomic benefits of foreign aid (Weisskoff, 1972; Mosely, 1986; Mosely and Hudson, 1995; Boone, 1996; Easterly, 2001). Their arguments stem from Olsen's (1965) ideas on free-rider problems and coordination failures. Foreign aid, according to these studies, creates free rider problems and a rent-seeking environment to the detriment of indigenous resource mobilization.

Considering the diversity of impacts of foreign aid, gradually empirical exploration extended beyond the domain of macroeconomic effectiveness, with economic freedom becoming one of the topics covered in the evolving foreign aid literature. We consider the streams of literature deliberating both direct and indirect effects of foreign aid on the economic freedom of recipient countries.

The indirect impacts of foreign aid on economic freedom take effect through a number of different transmission channels. For instance, some studies argued that the effect of foreign aid on economic freedom takes place through conditionality, since donor countries often directly tie the transfer of money to certain aims and conditions. Hence, the impact of foreign aid on economic freedom of the receiving country is conditional on both the nature of conditions imposed and donor country implementation capacity. Conditional aid does not always enhance economic freedom, however. For instance, Alesina and Dollar (2000), Meernik, et al. (1998), and Schraeder, et al. (1998) argue that during the Cold War era ${ }^{2}$ the provision of aid by the western nations to lessdeveloped nations were mainly tied to the attainment and safeguard of armed, tactical and political aims; hence, during this period, given the non-progressive nature of aid, economic freedom of the receiving countries could not improve.

Other researchers examined the role of the recipient country's own characteristics in the foreign aid -economic freedom relationship. This literature explored the mediating role of the institutional, governance,

${ }^{2}$ The state of political tension from1947-1991 after World War II. 
and political regimes. Aid can either strengthen or weaken economic institutions. The latter can occur when the substitutability of foreign aid for domestic revenue creates a rent-seeking environment. For instance, Devarajan et al. (2001) argue that aid receiving administrators take aid as an alternative source of revenue collection, whereas political leaders pursuing their own interests use aid in unproductive ways. Similarly, Heckelman and Knack (2009) found that aid had no impact on economic freedom in the receiving countries. Some others examine the role of the nature of the ruling party in the foreign aid and economic freedom relationship. Tawaiah, and Zakari (2019), for example, document that right-leaning, capitalist parties allocate more resources to create the enabling environment for the private sector while leftist parties allocate more aid inflows for the pro-poor projects such as short-term poverty reduction. For instance, Dutta and Williamson (2016a) carried out a comprehensive study and examined the impact of foreign aid on economic freedom conditional on the quality of political institutions using a data set of 108 countries from 1971 to 2010. They find that economic freedom improves with aid in countries that are democratic, but it has a negative impact in the case of autocracies.

\section{Methodology}

The methodology section includes four subsections; the first section 3.1 presents the specification of the empirical model. Section 3.2 describes the definition and construction of variables under consideration. Section 3.3 describes the sample and sample selection criteria, and section 3.4 presents the estimation techniques.

\subsection{Empirical Model}

Our empirical model is based largely on Dutta and Williamson's (2016a) empirical model which analyzes the impact of foreign aid on economic freedom conditional on political institutions. Hence, in order to examine the impact of different types of foreign aid on economic freedom and to explore the role of political institutions we closed follow Dutta and Williamson (2016a) and estimated the empirical model in Equation 1.We diverge from Dutta and Williamson (2016a) in two ways. First, since the presence of unobserved heterogeneity implies that estimates of common parameters are subject to an incidental parameter bias that may be 
substantial in large samples (Hahn and Newey, 2004), we reduce the sample to 40 countries. Further, these 40 countries are selected to be similar (having experienced both aid dependency and a transition in political regime), as Bonhomme and Manresa (2015) argue that grouped patterns of unobserved heterogeneity in cross country analyses reduce the incidental parameter bias. Secondly, unlike Dutta and Williamson (2016a) that used the overall foreign aid, we analyze the impact of different types of foreign aid on economic freedom. ${ }^{3}$

$$
\begin{aligned}
\mathrm{EF}_{\mathrm{it}}= & \alpha_{0}+\alpha_{1} \mathrm{EF}_{\mathrm{it}-1}+\beta \mathrm{AID}_{\mathrm{it}-1}+\gamma \mathrm{POLINST}_{\mathrm{it}-1}+\alpha_{3}\left(\mathrm{AID}_{\mathrm{it}-1} *\right. \\
& \text { POLINST } \left._{\mathrm{it}-1}\right)+\theta \mathrm{X}_{\mathrm{it}-1}+\eta_{\mathrm{i}}+\eta_{\mathrm{t}}+\varepsilon_{\mathrm{it}}
\end{aligned}
$$

Where economic freedom $\left(\mathrm{EF}_{\mathrm{it}}\right)$ is our dependent variable in country $i$ and period $t . \mathrm{EF}_{\mathrm{it}-1}$ is the lagged dependent variable, $\mathrm{AID}_{\mathrm{it}-1}$ represents foreign aid which is our variable of interest and covers two types of foreign assistance, that are Official Development Assistance (ODA) and Net Official Assistance (NOA). POLINST ${ }_{\text {it-1 }}$ represents lagged measures political institutions that comprise democracy and durability. $X_{i t-1}$ is the vector of control variables. $\eta_{i}$ is a country fixed effect, $\eta_{t}$ is a period fixed effects and $\varepsilon_{i t}$ is error term which is normally distributed.(AID $i t-1 *$ POLINST $_{i t-1}$ ) is the interaction term, which shows the impact of foreign aid on economic freedom conditional on the political institutional structure of country $i$.

\subsection{Definition and Construction of Variables}

The dependent variable is Economic Freedom $\left(\mathrm{EF}_{\mathrm{it}}\right)$ is and index composed of five components: i) Size of Government ii) Monetary Policy and Price Stability iii) Legal Structure and Security of Private Property iv) Freedom to Trade without Regulations v) Regulation of Credit, Labor and Business. The index value ranges from 0-10 with a higher score showing greater economic freedom ${ }^{4}$.

Among explanatory variables, foreign aid $\left(A I D_{i t-1}\right)$ is our main variable of interest. We have used two different measures of aid in our analysis, namely Official Development Assistance(ODA $\left.\mathrm{Ot}_{\mathrm{it}-1}\right)$ and Net

\footnotetext{
${ }^{3}$ Section 2.3 presents a detailed discussion on the selection criteria of Country's sample and time period.

${ }^{4}$ Data is available at www.Fraserinstitute.org.
} 
Official Assistance $\left(\mathrm{NOA}_{\mathrm{it}-1}\right)$. ODA, which is an extensive measure of assistance, is taken as a percentage of GNI. It contains concessional loans and grants and also bilateral and multilateral aid. Net Official Assistance is a flow from official donors to those in part II of the Development Assistance Committee (DAC) list of receivers, which is in current U.S. dollars. ${ }^{5}$ Moreover, because of potential endogeneity and reverse causation, foreign assistance is lagged and successively instrumented. The data on economic freedom and foreign assistance are taken from the Fraser Institute (2016) and the World Bank's World Development Indicators (WDI) 2016, respectively.

In order to capture the role of political institutions, we measure their quality (democracy) and stability (durability). The first component (democracy) ranges from +10 to -10 , where +10 represents strong democracy and -10 represents strong autocracy with a mean of 2.5 and a standard deviation of 6.0. The second component (durability) shows the number of years a political regime changes and ranges from 0 to 194 having a mean of 16.6 and a standard deviation of 21.7. The data on both are collected from the Polity IV database ${ }^{6}$.In order to capture the role of political institutions in the foreign aid -economic freedom nexus, we used a number of interaction terms in our empirical analysis. As two components of political institutions and two proxies of foreign aid are used, we obtain four different interaction terms, namely ODA with democracy $\left(O D A_{i t-1}\right.$ * $\left.D E M_{i t-1}\right)$, and ODA with durability $\left(O D A_{i t-1} * D U R_{i t-1}\right)$. In the same way, $\left(N O A_{i t-1} * D E M_{i t-1}\right)$ and $\left(N O A_{i t-1} * D U R_{i t-1}\right)$ are the interaction terms for net official assistance with democracy and net official assistance with durability respectively.

We used a set of control variables considering their relevance as a determinant of economic freedom and their potential for affecting the response of economic freedom to foreign aid. For instance, as suggested by Boockmann and Dreher (2003), economic freedom increases with

\footnotetext{
${ }^{5}$ In 1993 - with new aid requirements in the transition economies of Eastern Europe and reduced aid needs in East Asia due to rapid progress - a new list was devised. It was divided into two parts. Part I: Only aid to "traditional" developing countries counted as Official Development Assistance (ODA), for which there is a long-standing United Nations target of $0.7 \%$ of donors' national income. Part II: Aid to "more advanced" developing and eastern European countries were recorded separately as "official aid". Net Official Assistance (NOA) is provided to emerging nations on the same terms and conditions as in the case of ODA.

${ }^{6}$ Available at www.systemicpeace.org/inscrdata.html.
} 
economic prosperity. Similarly, Knedlik and Kronthaler (2007), Heckelman and Knack (2005), and Dreher and Gehring (2012) argued that as a country becomes richer, its citizens may demand more economic freedom. Hence, in order to capture the growth effect on economic freedom, we used lagged GDP growth $\left(\mathrm{GDPG}_{\mathrm{it}-1}\right)$ and lagged GDP per capita $\left(\mathrm{GDPPC}_{\mathrm{it}-1}\right)$ as control variables.

We control for population growth $\left(\mathrm{POPG}_{\mathrm{it}-1}\right)$ in our empirical model for the following reasons. First, population growth provides an opportunity for the accumulation of human capital, which is essential to economic freedom. Second, economic activity increases with an increase in population, and with it the opportunities to pursue economic freedom. Third, population growth yields positive dividends for the younger population who will want to claim more economic freedom as indicated by Young and Sheehan (2014). In addition, it is generally proposed that when a greater share of the working-age population are engaged in production, then they desire more economic freedoms. In this context, labor force participation $\left(\mathrm{LFPR}_{\mathrm{it}-1}\right)$ is also controlled for in our empirical model. Finally, we include trade openness $\left(\mathrm{TOPEN}_{\mathrm{it}-1}\right)$ to control for exposure to the rest of the world. Data on these variables are collected from WDI data set of the World Bank7.

\subsection{Country's Sample and Time Period Selection Criteria}

We carry out the analysis on a cross-country panel of 40 developing countries selected from four different aid-receiving regions. ${ }^{8}$ Within these regions, three motives limit our analysis to a sample of 40 countries only. First, few of the sample countries have sufficiently mobilized their own indigenous resources, so that their development is firmly contingent on external sources. Second, the sample countries share some common characteristics; for instance, most of the countries have large governments, highly regulated monetary and exchange rate regimes, a lack of legal structure and security of private property, which limits their economic freedom. Finally, most of the sample countries have passed through a transitional period of their political system, so that they have experienced both democracy and autocracy. Owing to these

\footnotetext{
${ }^{7}$ See appendix A for definition and construction of variables under consideration.

${ }^{8}$ These four regions are South Asia, East Asia, Latin America, and Sub-Saharan Africa. See appendix B for the list of countries under consideration.
} 
characteristics, the economic freedom of these countries should be affected by foreign aid and political institutions.

The time period from 1985-2016 reflects data availability and the history of donor conditionalities. First, a long time series for those critical variables including economic freedom and political institutions is not available. Second, most of the conditionalities have only been enforced since the early 1990s.

\section{Empirical Methodology}

In estimating (1), we have to consider the issues of heterogeneity across cross-sections and endogeneity with respect to foreign aid (Fuchs et al., 2014; Dutta and Williamson, 2016a). With regards to the importance cross-sectional heterogeneity, the Breusch-Pagan heterogeneity test shows that in all specifications the null hypothesis ( $\widehat{\sigma}^{2}=0$ constant variance) is rejected, indicating that cross-country specific fixed effects matter. ${ }^{9}$

Second, to handle the endogeneity problem, we estimated equation (1) with two different estimation techniques: Instrumental Variables (IV) and System GMM techniques. As foreign aid and its interaction terms subject to reverse causality, they are treated as endogenous variables and are instrumented for. The generated instruments (GMM) come from moment conditions for the dynamic panel estimators, whereas the external instruments (IV) have come from the received literature (Fuchs et al. 2014; Dutta and Williamson, 2016a). These studies have focused on voting alignment with major supporters in the United Nations General Assembly (UNGA) and impermanent affiliation in United Nations Security Council (UNSC). Following these authors, we use the same variables as external instruments. The first instrument is polling coincidence with chief aid givers in the UNGA. Barro and Lee (2015) argue that the developing countries that have a closer tie with the US can indeed get more aid inflows as compared to other developing countries. Second, an instrument that has been used is the main polls in the UNGA, which are in line with the elective configuration of major aid donor countries like Great Britain, United States, Italy, Japan, and France. These two variables are lagged one period. The third instrument is the temporary membership in the United

\footnotetext{
${ }^{9}$ See appendix C for the Breusch-Pagan heterogeneity test.
} 
Nation Security Council (UNSC), since empirical studies show that countries that have temporary membership in the council may receive relatively more aid than non-members counterparts.

Next, we move towards GMM estimation that generates instruments through moment conditions for the variable of interest (foreign aid) and its interaction terms. Taking aid and its interaction terms endogenous, system GMM gives two sets of equations that are in level and difference forms (Fuchs et al. 2014).

The GMM estimators utilize internal instruments using a lag of the dependent and previous observations of explanatory variables, which addresses endogeneity problems. However, the difference GMM estimator has some noteworthy shortcomings as specified by AlonsoBorrego and Arellano (1999), and Bond et.al (2001) that, in the case of difference regression, equation lagged levels of variables are weak instruments that in turn cause bias and inefficiency in the estimated regressions. Hence, to reduce these potential pitfalls in our estimator, we use the system GMM estimator developed by Arellano and Bover (1995) that use both differences and levels regression equations and combine them into one system. The consistency of the GMM estimator depends on the validity of the instruments used. For addressing this problem, we used two specification tests suggested by Arellano and Bover (1995). The first is the Sargan test to test the validity of all instruments used. The Sargan test tests the null hypothesis of the validity of over-identifying instruments. The second test is that of serial correlation to test whether error terms are second-order serial correlated.

We have carried our estimations with eight different specifications. First, we have examined directly the impact of aid on economic freedom using two different types of foreign aid namely ODA, and NOA. Second, we examined the impact of foreign aid on economic freedom conditional on political institutions (democracy, durability). Finally, the robustness of estimated results has been checked in the last two specifications.

\section{Empirical Findings}

The following subsections 4.1 and 4.2 present the estimated results of IV and GMM estimation techniques respectively. 


\subsection{Estimation}

Table 1 presents the estimated results of our IV empirical model where we regressed economic freedom $\left(\mathrm{EF}_{\mathrm{it}}\right)$ on two different proxies of foreign aid along with conditional terms and a set of control of variables. In order to address the endogeneity of foreign, we used six external instrumental variables.

Table 1. IV Estimated Results (Dependent Variable is Economic Freedom)

\begin{tabular}{|c|c|c|c|c|c|c|c|c|}
\hline Variables & (1) & (2) & (3) & (4) & (5) & (6) & (7) & (8) \\
\hline Const. & $\begin{array}{l}4.862^{*} \\
(0.000)\end{array}$ & $\begin{array}{l}4.034^{*} \\
(0.000)\end{array}$ & $\begin{array}{l}3.954^{*} \\
(0.000)\end{array}$ & $\begin{array}{l}4.314^{*} \\
(0.000)\end{array}$ & $\begin{array}{l}3.933^{*} \\
(0.000)\end{array}$ & $\begin{array}{l}4.191^{*} \\
(0.000)\end{array}$ & $\begin{array}{l}3.945^{*} \\
(0.000)\end{array}$ & $\begin{array}{l}3.961^{*} \\
(0.000)\end{array}$ \\
\hline $\mathrm{EF}_{\mathrm{it}-1}$ & $\begin{array}{l}0.803^{*} \\
(0.000)\end{array}$ & $\begin{array}{l}0.811^{*} \\
(0.000)\end{array}$ & $\begin{array}{l}0.833^{*} \\
(0.000)\end{array}$ & $\begin{array}{l}0.890 \text { * } \\
(0.000)\end{array}$ & $\begin{array}{l}0.835^{*} \\
(0.000)\end{array}$ & $\begin{array}{l}0.811^{*} \\
(0.000)\end{array}$ & $\begin{array}{l}0.851^{*} \\
(0.000)\end{array}$ & $\begin{array}{l}0.854^{*} \\
(0.000)\end{array}$ \\
\hline $\mathrm{GDPG}_{\mathrm{it}-1}$ & $\begin{array}{l}0.511^{* *} \\
(0.034)\end{array}$ & $\begin{array}{l}0.024^{* *} \\
(0.036)\end{array}$ & $\begin{array}{l}0.026^{* *} \\
(0.033)\end{array}$ & $\begin{array}{c}0.020^{* *} \\
(0.05)\end{array}$ & $\begin{array}{l}0.038^{*} \\
(0.003)\end{array}$ & $\begin{array}{c}0.016^{* * *} \\
(0.076)\end{array}$ & $\begin{array}{c}0.250^{* * *} \\
(0.061)\end{array}$ & $\begin{array}{l}0.252^{* *} \\
(0.053)\end{array}$ \\
\hline $\mathrm{POPG}_{\mathrm{it}-1}$ & $\begin{array}{c}-0.113 \\
(0.233)\end{array}$ & $\begin{array}{l}-0.009 \\
(0.697)\end{array}$ & $\begin{array}{l}-0.016 \\
(0.583)\end{array}$ & $\begin{array}{l}-0.030 \\
(0.293)\end{array}$ & $\begin{array}{l}-0.008 \\
(0.803)\end{array}$ & $\begin{array}{l}-0.024 \\
(0.182)\end{array}$ & $\begin{array}{l}-0.33 \\
(0.266)\end{array}$ & $\begin{array}{l}-0.354 \\
(0.234)\end{array}$ \\
\hline $\mathrm{LFPR}_{\mathrm{it}-1}$ & $\begin{array}{l}0.017^{*} \\
(0.000)\end{array}$ & $\begin{array}{l}0.023^{*} \\
(0.000)\end{array}$ & $\begin{array}{l}0.022^{*} \\
(0.000)\end{array}$ & $\begin{array}{l}0.015^{*} \\
(0.000)\end{array}$ & $\begin{array}{l}0.133^{*} \\
(0.000)\end{array}$ & $\begin{array}{l}0.015^{* *} \\
(0.029)\end{array}$ & $\begin{array}{l}0.031^{*} \\
(0.000)\end{array}$ & $\begin{array}{l}0.028^{*} \\
(0.000)\end{array}$ \\
\hline$O D A_{\text {it }-1}$ & $\begin{array}{c}-0.105^{* *} \\
(0.000)\end{array}$ & - & $\begin{array}{l}-0.072^{*} \\
(0.008)\end{array}$ & - & $\begin{array}{l}-0.046^{*} \\
(0.001)\end{array}$ & - & $\begin{array}{l}-0.07^{*} \\
(0.002)\end{array}$ & $\begin{array}{l}-0.066^{*} \\
(0.003)\end{array}$ \\
\hline$N O A_{\text {it }-1}$ & - & $\begin{array}{c}-0.104^{* *} \\
(0.042)\end{array}$ & - & $\begin{array}{l}-0.434^{*} \\
(0.000)\end{array}$ & - & $\begin{array}{c}-0.222^{* *} \\
(0.028)\end{array}$ & - & - \\
\hline $\mathrm{DEM}_{\mathrm{it}-1}$ & $\begin{array}{l}0.038^{*} \\
(0.000)\end{array}$ & $\begin{array}{l}0.009^{*} \\
(0.000)\end{array}$ & $\begin{array}{c}0.018^{*} \\
(0.000)\end{array}$ & $\begin{array}{l}0.024^{*} \\
(0.000)\end{array}$ & $\begin{array}{l}0.022^{* *} \\
(0.054)\end{array}$ & $\begin{array}{l}0.017^{*} \\
(0.000)\end{array}$ & $\begin{array}{l}0.021^{*} \\
(0.001)\end{array}$ & $\begin{array}{l}0.020^{*} \\
(0.000)\end{array}$ \\
\hline DUR $_{\text {it }-1}$ & $\begin{array}{l}0.003^{* *} \\
(0.033)\end{array}$ & $\begin{array}{l}0.004^{*} \\
(0.001)\end{array}$ & - & - & $\begin{array}{l}0.007^{*} \\
(0.001)\end{array}$ & $\begin{array}{l}0.043^{*} \\
(0.000)\end{array}$ & 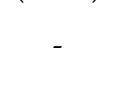 & - \\
\hline $\begin{array}{l}\left(\mathrm{ODA}_{\mathrm{it}-1}\right. \\
\left.* \mathrm{DEM}_{\mathrm{it}-1}\right)\end{array}$ & - & - & $\begin{array}{l}0.009^{*} \\
(0.000)\end{array}$ & - & - & - & $\begin{array}{c}0.0015^{* *} \\
(0.074)\end{array}$ & $\begin{array}{l}0.003^{* *} \\
(0.028)\end{array}$ \\
\hline $\begin{array}{l}\left(\mathrm{NOA}_{\mathrm{it}-1}\right. \\
\left.* \mathrm{DEM}_{\mathrm{it}-1}\right)\end{array}$ & - & - & - & $\begin{array}{l}0.076^{*} \\
(0.000)\end{array}$ & - & - & - & - \\
\hline $\begin{array}{l}\left(\mathrm{ODA}_{\mathrm{it}-1}\right. \\
\left.\text { * } \mathrm{DUR}_{\mathrm{it}-1}\right)\end{array}$ & - & - & - & - & $\begin{array}{l}0.001^{* *} \\
(0.041)\end{array}$ & - & - & - \\
\hline $\begin{array}{l}\left(\mathrm{NOA}_{\mathrm{it}-1}\right. \\
\left.\text { * } \mathrm{DUR}_{\mathrm{it}-1}\right)\end{array}$ & - & - & - & - & - & $\begin{array}{c}0.008^{*} \\
(0.003)\end{array}$ & - & - \\
\hline TOPEN $_{\text {it }-1}$ & - & - & - & - & - & - & $\begin{array}{l}0.010^{*} \\
(0.000)\end{array}$ & $\begin{array}{l}0.010^{*} \\
(0.01)\end{array}$ \\
\hline $\mathrm{GDPPC}_{\mathrm{it}-1}$ & - & - & - & - & - & - & - & $\begin{array}{l}0.023^{*} \\
(0.003)\end{array}$ \\
\hline $\mathrm{R}^{2}$ & 0.77 & 0.78 & 0.77 & 0.71 & 0.76 & 0.78 & 0.76 & 76 \\
\hline Obs. & 1279 & 1273 & 1279 & 1273 & 1279 & 1274 & 1279 & 1279 \\
\hline No. of Ins. & 12 & 12 & 12 & 12 & 12 & 12 & 12 & 12 \\
\hline Sargan P. & 0.67 & 0.45 & 0.75 & 0.31 & 0.01 & 0.70 & 0.75 & 0.45 \\
\hline
\end{tabular}

Note: $\mathrm{P}$-value is in parenthesis, ${ }^{*},{ }^{* *},{ }^{* *}$ shows level of significance at $1 \%, 5 \%$, and $10 \%$ respectively.

Source: Authors' calculations. 
In table 1 , model 1 illustrates the direct effect of foreign aid on economic freedom of the aid receiving country. The result shows that foreign aid captured by official development assistance $\left(\mathrm{ODA}_{\mathrm{it}-1}\right)$ enters the model with a negative sign, which is statistically significant. The result indicates that official development assistance has a negative effect on the economic freedom of the receiving countries. The following reasons may explain why foreign aid may pose a negative impact on economic freedom. For instance, Heckelman and Knack (2008) stated that foreign aid can prove ruinous for economic freedom in those countries that are continuously receiving foreign aid but never taking up growth-related reforms. Powell and Rayan (2006), Dutta and Williamson (2016a) stated that foreign aid has a negative effect on economic freedom in aid receiving countries where strict rules have little regard to the wishes and welfare of their people.

In model 2, official development assistance is replaced with the net official assistance $\left(\mathrm{NOA}_{\mathrm{it}-1}\right)$. Like ODA, the coefficient on net official assistance maintains a negative sign, which is also statistically significant. This points toward the statement that economic freedom shrinks with foreign aid of any kind. The results are in line with the findings of Powell and Ryan (2006); Heckelman and Knack (2008); Dreher et al. (2015), and Dutta and Williamson (2016a). In both models $(1,2)$ political institutions, measure as democracy $\left(D E M_{i t-1}\right)$ and durability $\left(D U R_{i t-1}\right)$ enter the model positively and statistically significant. The result indicates that countries enjoy more economic freedom when their political institutions are either more democratic or more durable (or both).

As the study is devoted to exploring the joint role of political institutions and foreign aid on economic freedom, different interaction terms of foreign aid and political institutions have been included as explanatory variables. In models 3and 4 we considered the interaction terms of ODA and democracy $\left(\mathrm{ODA}_{\mathrm{it}-1} * \mathrm{DEM}_{\mathrm{it}-1}\right)$ and net official aid and democracy $\left(\mathrm{NOA}_{\mathrm{it}-1} * \mathrm{DEM}_{\mathrm{it}-1}\right)$, and they are each statistically significant; this signifies the important role of democratic institutions for the effectiveness of both types of aid in increasing economic freedom. In democratic regimes, the representative body generally uses foreign aid for the interests of the public rather than for their own benefits as in the case of 
autocratic regimes. Dutta and Williamson (2016a), Dutta et al. (2013), Bearce and Tirone (2010) and Dunning (2004) found similar results.

In models 5 and 6 , the role of political stability is investigated. In this context, the interaction terms of official development assistance and durability $\left(\mathrm{ODA}_{\mathrm{it}-1} * \mathrm{DUR}_{\mathrm{it}-1}\right)$ and net official assistance and durability $\left(\mathrm{NOA}_{\mathrm{it}-1} * \mathrm{DUR}_{\mathrm{it}-1}\right)$ are used in order to analyze the role of durable political rules in foreign aid's efficacy in enhancing economic freedom. The interaction terms each enter the model positively and significantly, indicating that countries which hold durable political rules gain greater benefits from ODA and NOA through greater economic freedom. Johnson and Subramanian (2005) argued that foreign aid had no ability to improve institutions by itself, but already improved ones could use foreign aid for progressive purposes that in turn increased demand for economic freedom.

In models 7 and 8, the role of the political regime (democracy) is again investigated in foreign aid and economic freedom nexus by adding more control variables in the model. The estimated values of interaction terms show that, with the inclusion of control variables trade openness $\left(\mathrm{TOPEN}_{\mathrm{it}-1}\right)$, and GDP per capita $\left(\mathrm{GDPC}_{\mathrm{it}-1}\right)$, the estimated coefficients of the variables of interest and interaction terms remain unchanged.

The control variables GDP growth $\left(\mathrm{GDPG}_{\mathrm{it}-1}\right)$, population growth $\left(\mathrm{POPG}_{\mathrm{it}-1}\right)$, labor force participation $\left(\mathrm{LFPR}_{\mathrm{it}-1}\right)$ are common to all specifications. Results presented in Table 1 shows that, except for population growth, these variables are important in the determination of economic freedom. GDP growth positively contributes to economic freedom in line with the literature; for example, Boockmann and Dreher (2003) argue that as a country becomes richer its citizens may demand more economic freedom. The coefficient on population growth $\left(\mathrm{POPG}_{\mathrm{it}-1}\right)$ maintainsis negative but it is statistically insignificant in all specifications. The result does not support the Young and Sheehan (2014) hypothesis that a larger population lays claim to more economic freedom. Labor force participation $\left(\mathrm{LFPR}_{\mathrm{it}-1}\right)$ is significant and positively related to economic freedom. This may be due to the reason that when more people are employed then they may be empowered to demand greater economic freedoms. Trade openness $\left(T O P E N_{i t-1}\right)$ has a positive 
effect on economic freedom. Coviello and Islam (2006) and Knedlik and Kronthaler (2007) obtained similar findings for the relationship between economic freedom and trade openness. The model is dynamic as the lagged dependent variable $\left(E F_{i t-1}\right)$ has been introduced as an explanatory variable. The coefficient of $E F_{i t-1}$ is positive and highly significant across all of the specifications. This indicates that existing economic freedom is strongly influenced by its past level.

\subsection{GMM Estimation}

An alternate method to address the problem of endogeneity is the GMM estimation technique, using its own generated instrumental variables. Table 2 presents the GMM estimated results of our eight different specifications. 
Table 2: GMM Estimated Results (Dependent Variable is Economic Freedom)

\begin{tabular}{|c|c|c|c|c|c|c|c|c|}
\hline Variables & (1) & (2) & (3) & (4) & (5) & (6) & (7) & (8) \\
\hline \multirow[t]{2}{*}{$\mathrm{EF}_{\mathrm{it}-1}$} & $0.762^{*}$ & $0.754^{*}$ & $0.791^{*}$ & $0.762^{*}$ & $0.774^{*}$ & $0.760^{*}$ & $0.752^{*}$ & $0.755^{*}$ \\
\hline & $(0.000)$ & $(0.000)$ & $(0.000)$ & $(0.000)$ & $(0.000)$ & $(0.00)$ & $(0.000)$ & $(0.000)$ \\
\hline \multirow[t]{2}{*}{$\mathrm{GDPG}_{\mathrm{it}-1}$} & $0.030^{* *}$ & $0.033^{*}$ & -0.004 & $0.0345^{*}$ & $0.026^{* *}$ & $0.037^{*}$ & $0.02^{* * *}$ & $0.02^{* * *}$ \\
\hline & $(0.048)$ & $(0.007)$ & $(0.273)$ & $(0.004)$ & $(0.028)$ & $(0.002)$ & (0.094) & $(0.08)$ \\
\hline \multirow[t]{2}{*}{$\mathrm{POPG}_{\mathrm{it}-1}$} & -0.05 & -0.090 & -0.91 & -0.75 & -0.093 & -0.074 & -0.068 & -0.014 \\
\hline & (0.104) & $(0.211)$ & $(0.201)$ & (0.110) & $(0.141)$ & $(0.202)$ & (0.113) & $(0.212)$ \\
\hline \multirow[t]{2}{*}{$\mathrm{LFPR}_{\mathrm{it}-1}$} & $0.015^{*}$ & $0.013^{*}$ & $0.025^{*}$ & $0.018^{*}$ & $0.046^{*}$ & $0.030^{* *}$ & $0.035^{*}$ & $0.022^{*}$ \\
\hline & $(0.000)$ & $(0.000)$ & $(0.000)$ & $(0.000)$ & $(0.000)$ & (0.029) & $(0.000)$ & (0.000) \\
\hline \multirow[t]{2}{*}{$\mathrm{ODA}_{\mathrm{it}-1}$} & $-0.011^{* *}$ & & -0.011 & & $-0.010^{* *}$ & . & $-0.011^{* *}$ & $-0.011^{* *}$ \\
\hline & $(0.024)$ & - & $(0.164)$ & - & $(0.020)$ & 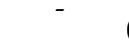 & $(0.043)$ & $(0.041)$ \\
\hline $\mathrm{NOA}_{\mathrm{it}-1}$ & - & $\begin{array}{c}0.036^{* *} \\
(0.031)\end{array}$ & - & $\begin{array}{l}0.039^{* *} \\
(0.022)\end{array}$ & - & $\begin{array}{c}0.013^{* * *} \\
(0.07)\end{array}$ & - & - \\
\hline \multirow[t]{2}{*}{$\mathrm{DEM}_{\mathrm{it}-1}$} & $0.027^{*}$ & $0.021^{*}$ & $0.033^{*}$ & 0.578 & & & $0.027^{*}$ & $0.026^{*}$ \\
\hline & $(0.002)$ & $(0.000)$ & $(0.002)$ & (0.109) & - & - & $(0.004)$ & (0.005) \\
\hline \multirow[t]{2}{*}{$\mathrm{DUR}_{\mathrm{it}-1}$} & $0.003^{* *}$ & $0.004^{* *}$ & 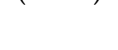 & 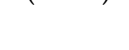 & $0.005^{* * *}$ & $0.014^{* * *}$ & 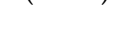 & 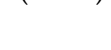 \\
\hline & $(0.012)$ & $(0.044)$ & - & - & $(0.063)$ & $(0.082)$ & - & - \\
\hline $\begin{array}{l}\mathrm{ODA}_{\mathrm{it}-1} \\
* \mathrm{DEM}_{\mathrm{it}-1}\end{array}$ & - & - & $\begin{array}{c}0.001^{* * *} \\
(0.073)\end{array}$ & - & - & - & $\begin{array}{l}0.006^{* *} \\
(0.036)\end{array}$ & $\begin{array}{l}0.006^{* *} \\
(0.039)\end{array}$ \\
\hline $\begin{array}{l}\mathrm{NOA}_{\mathrm{it}-1} \\
* \mathrm{DEM}_{\mathrm{it}-1}\end{array}$ & - & - & - & $\begin{array}{l}0.001^{* *} \\
(0.041)\end{array}$ & - & - & - & - \\
\hline $\begin{array}{l}\text { ODA }_{\text {it-1 }} \\
* \text { DUR }_{i t-1}\end{array}$ & - & - & - & - & $\begin{array}{l}0.003^{* *} \\
(0.047)\end{array}$ & - & - & - \\
\hline $\begin{array}{l}\text { NOA }_{\text {it-1 }} \\
* \mathrm{DUR}_{\mathrm{it}-1}\end{array}$ & - & - & - & - & - & $\begin{array}{l}0.007^{* *} \\
(0.030)\end{array}$ & - & - \\
\hline TOPEN $_{\mathrm{it}-1}$ & - & - & - & - & - & - & $\begin{array}{l}0.001^{* *} \\
(0.049)\end{array}$ & $\begin{array}{l}0.001^{* *} \\
(0.041)\end{array}$ \\
\hline $\mathrm{GDPPC}_{\mathrm{it}-1}$ & - & - & - & - & - & - & - & $\begin{array}{l}0.006^{* * *} \\
(0.078)\end{array}$ \\
\hline $\mathrm{R}^{2}$ & 0.58 & 0.60 & 0.62 & 0.57 & 0.63 & 0.60 & 0.61 & 0.62 \\
\hline Obs. & 1199 & 1193 & 1199 & 1193 & 1199 & 1193 & 1199 & 1199 \\
\hline No. of Ins. & 482 & 482 & 483 & 483 & 483 & 484 & 485 & 486 \\
\hline Sargan P. Value & 0.34 & 0.37 & 0.54 & 0.31 & 0.40 & 0.37 & 0.45 & 0.35 \\
\hline $\begin{array}{l}\text { P Value of } \\
\text { Auto-Corr. }\end{array}$ & 0.35 & 0.50 & 0.33 & 0.45 & 0.41 & 0.33 & 0.36 & 0.41 \\
\hline
\end{tabular}

Note: $\mathrm{P}$-value is in parenthesis, ${ }^{*}, * *, * *$ shows level of significance at $1 \%, 5 \%$, and $10 \%$ respectively.

Source: Authors' calculations.

Model 1 shows that like the IV results, official development assistance $\left(\mathrm{ODA}_{\mathrm{it}-1}\right)$ enters the model negatively. In model $2, \mathrm{ODA}$ is replaced with net official assistance $\left(\mathrm{NOA}_{\mathrm{it}-1}\right)$. As opposed to the IV estimation, in GMM estimation net official assistance has a positive and significant impact. 
To explore the role of political institutions in foreign aid, economic growth relationship, in model 3 and 4 we included the interaction terms of ODA and democracy $\left(\mathrm{ODA}_{\mathrm{it}-1} * \mathrm{DEM}_{\mathrm{it}-1}\right)$ and net official assistance and democracy $\left(\mathrm{NOA}_{\mathrm{it}-1} * \mathrm{DEM}_{\mathrm{it}-1}\right)$. Like the IV results, the interaction terms are positive and statistically significant.

In model 5 and 6, we investigated the role of political stability (durability) $\mathrm{DUR}_{\mathrm{it}}$ on the foreign aid - economic freedom relationship. Durability has a positive and statistically significant impact indicating that countries enjoy more economic freedom when they have a relatively stable political system. At the same time, like the IV estimates, the interaction terms of ODA and durability $\left(\mathrm{ODA}_{\mathrm{it}-1} * \mathrm{DUR}_{\mathrm{it}-1}\right)$ and of net official assistance and durability $\left(\mathrm{NOA}_{\mathrm{it}-1} * \mathrm{DUR}_{\mathrm{it}-1}\right)$ enter the model positively and significantlyhave significantly positive impacts, indicating that foreign aid does best in raising economic freedom when the country's political rules are more durable.

In models 7 and 8 , the role of democracy is re-examined after we add more control variables into the model. The estimated coefficients of democracy and its interactions with the different measures of aid are unchanged with the inclusion of the additional control variables.

\subsection{Robustness Checks}

The empirical analysis carried out with both IV and GMM estimation techniques. However, the consistency of IV and GMM estimator depends on the validity of instruments used in the regression. Since the null hypothesis of Sargan test is that over-identifying restrictions are valid, acceptance of the null hypothesis gives support to the model. For both the IV and GMM estimates in Tables1 and 2, the p-values of the Sargan test shows that the null hypothesis is not rejected in all eight specifications, which indicates that the instruments are correctly specified. Next, in the case of the GMM estimation, the serial correlation property of the original error term is tested as suggested by Arellano and Bond (1991). The p-value of second-order serial correlation presented in Table 2 indicates that the null hypothesis no serial correlation is not rejected. This indicates that the original error term is not serial correlated. Hence, we cannot reject the validity of the proposed instrument (one lag of dependent variable is a valid instrument) and do not require higher-order lags of the dependent variable. 


\section{Conclusion}

Foreign aid is one of the important external sources for financing growth and development in many countries. However, very often, donors put conditions that can shape the economic freedoms of the recipient country. Hence, is important to investigate the effect of foreign aid on the economic freedom of the recipient countries. Moreover, many of the conditions attached to foreign aid are governance-related, which suggests that it important to investigate the role of political institutions as mediators. This study thus attempted to analyze the effect of foreign aid on economic freedom and explore the role of political institutions as mediators. The findings of the study reveal that, by themselves, both types of foreign aid (ODA, NOA) have a negative effect on economic freedom in most specifications. Besides, the empirical evidence shows that political institutions (democracy and durability) influence the impact of foreign aid has on economic freedom. This is shown by the fact that in all of our estimated specifications, the interaction terms have a positive coefficient. The positive effect of foreign aid on economic freedom of the receiving countries is specific to more democratic regimes. Similarly, the evidence indicates that foreign aid proves more helpful in countries that have more durable political rules.

Despite certain limitations of the study, including limited sample size, we believe our findings contribute to the literature on the effects of foreign aid on economic freedom. Our findings reveal a positive impact of foreign aid on economic freedom are more likely in the presence of democracy and durability in the political rules. These results suggest the role of state policies aimed at strengthening political institutions in order to obtain the maximum benefits of foreign aid in terms of growth and development. 


\section{References}

Alesina, A., and Dollar, D. (2000). Who gives foreign aid to whom and why? Journal of economic growth,5(1), 33-63.

Arellano, M., and Bover, O. (1995). Another look at the instrumental variable estimation of error-components models. Journal of econometrics, 68(1), 29-51.

Altincekic, C., and Bearce, D. H. (2014). Why there should be no political foreign aid curse. World Development, 64, 18-32.

Arellano, M., and Bond, S. (1991). Some tests of specification for panel data: Monte Carlo evidence and an application to employment equations. The review of economic studies, 58(2), 277-297.

Alonso-Borrego, C., and Arellano, M. (1999). Symmetrically normalized instrumental-variable estimation using panel data. Journal of Business and Economic Statistics, 17(1), 36-49.

Bacha, E. L. (1990). A three-gap model of foreign transfers and the GDP growth rate in developing countries. Journal of Development economics,32(2), 279-296.

Barro, R. J., and Lee, J.-W. (2015). Education matters. Global schooling gains from the 19th to the 21st century, Oxford University Press.

Bearce, D.H., and Tirone, D.C. (2010). Foreign aid effectiveness and the strategic goals of donor governments. The Journal of Politics, 72(3), 837-851.

Birdsall, N. (2007). Do no harm: Aid, weak institutions and the missing middle in Africa. Development Policy Review, 25(5), 575-598.

Boockmann, B., and Dreher, A. (2003). The contribution of the IMF and the World Bank to economic freedom. European Journal of Political Economy, 19(3), 633-649.

Bond, S. R., Hoeffler, A., and Temple, J. R. (2001). GMM estimation of empirical growth models. 
Bonhomme, S., and Manresa, E. (2015). Grouped Patterns of Heterogeneity in Panel Data. Econometrica, 83 (3): 1147-1184.

Boone, P. (1996). Politics and effectiveness of foreign aid. American Economic Review, 40(2), 289-329.

Burnside, C., and Dollar, D. (2000). Aid, policies and growth. American Economic Review, 90 (4), 847-868.

Chenery, H. B., and Strout, A. M. (1966). Foreign assistance and economic development. American Economic Review, 56(4), 679-733.

Coviello, D., and Islam, R. (2006). Does aid help improve economic institutions? World Bank Policy Research Working Paper, 3990 (August).

Devarajan, S., Dollar, D., and Holmgren, T. (2001). Aid and reform in Africa: Lessons from ten case studies. World Bank Publications.

Dreher, A., and Gehring, K. (2012). Does aid buy (economic) freedom? Economic Freedom of the World 2012 Annual Report, 219-246.

Dreher., Langlotz, S., and Lohmann, S. (2015). Does foreign aid affect growth? VoxEU.

Duch, R. M. (2001). A developmental model of heterogeneous economic voting in new democracies. American Political Science Review, 95(4), 895-910.

Dunning, T. (2004). Conditioning the effects of aid: Cold war politics, donor credibility, and democracy in Africa. International Organization, 58, 409-423.

Dutta, N., Leeson, P. T., and Williamson, C. R. (2013). The amplification effect: Foreign aid's impact on political institutions. Kyklos, 66(2), 208-228.

Dutta, N., and Williamson, C. R. (2016a). Aiding economic freedom: Exploring the role of political institutions. European Journal of Political Economy, 45, 24-38. 
Easterly, W. (2001). The political economy of growth without development: A case study of Pakistan. Paper for the Analytical Narratives of Growth Project. Kennedy School of Harvard University.

Friedman, M. (1962). Capitalism and freedom. University of Chicago press, Chicago.

Fuchs, A., Dreher, A., and Nunnenkamp, P. (2014). Determinants of donor generosity: A survey of the aid budget literature. World Development, 56, 172-199.

Goldsmith, A. A. (2001). Foreign aid and statehood in Africa. International organization, 55(1), 123-148.

Gwartney, J., Lawson, R., and Norton, S. (2015). Economic freedom of the world 2008 annual report. The Fraser Institute.

Hahn, J. and Newey, W. (2004). Jackknife and analytical bias reduction for non-linear panel models. Econometrica, 72(4), 1295-1319.

Heckelman, J. C., and Knack, S. (2005). Foreign aid and market-liberalizing reform. World Bank Policy Research Working Paper, 3357, April, 2005.

Heckelman, J. C., and Knack, S. (2009). Aid, economic freedom, and growth. Contemporary Economic Policy, 27(1), 46-53.

Islam, A. (1992). Foreign aid and economic growth: An econometric study of Bangladesh. Applied Economics, 24(5), 541-544.

Johnson, S., and Subramanian, A. (2005). Aid, governance, and the political economy: Growth and institutions. Paper presented at the IMF paper presented at the Seminar on Foreign Aid and Macroeconomic Management, Maputo.

Juselius, K., Møller, N. F., and Tarp, F. (2014). The long run impact of foreign aid in 36 African countries: Insights from multivariate time series analysis. Oxford Bulletin of Economics and Statistics, 76(2), 153-184. doi: 10.1111/obes.12012. 
Knedlik, T., and Kronthaler, F. (2007). Aid and economic freedom: An empirical investigation using the heritage index. Journal of Development Perspectives Volume, 3(1), 116-135.

Marshall, M. G., Jaggers, K., and Gurr, T. R. (2014). Polity IV annual timeseries, 1800-2013. Center for International Development and Conflict Management at the University of Maryland College Park.

Meernik, J., Krueger, E. L., and Poe, S. C. (1998). Testing models of US foreign policy: Foreign aid during and after the Cold War. The Journal of Politics, 60(1), 63-85.

Mohtadi, H., and Roe, T. L. (2003). Democracy, rent seeking, public spending and growth. Journal of Public Economics, 87(3-4), 445-466.

Mosely, P. (1986). Aid Effectiveness: the micro-macro paradox. Institute of Development Studies Bulletin, 17(1), 214-225.

Mosley, P., and J. Hudson. (1995). Aid effectiveness: A study of the effectiveness of overseas aid in the main countries receiving ODA. Mimeo.

Olson, M. (1965). The logic of collective action, public goods and the theory of groups. Cambridge: Harvard University Press.

Papanek, G. F. (1973). Aid, foreign private investment, savings, and growth in less developed countries. Journal of Political Economy, 81(1), 120-130.

Powell, B., and Ryan, M. E. (2006). Does development aid lead to economic freedom? Journal of Private Enterprise, 22(1), 1.

Rajan, R., and Subramanian, A. (2007). Does aid affect governance? American Economic Review, 97(2), 322-327.

Rajan, R. G., and Subramanian, A. (2005). What undermines aid's impact on growth? National Bureau of Economic Research. 
Schraeder, P. J., Hook, S. W., and Taylor, B. (1998). Clarifying the foreign aid puzzle: A comparison of American, Japanese, French, and Swedish aid flows. World Politics, 50(2), 294-323.

Smith, A. (1776). An inquiry into the nature and causes of the wealth of nations. Dublin, Whitestone, 3.

Svensson, J. (2000). When is foreign aid policy credible? Aid dependence and conditionality. Journal of Development Economics, 61(1), 61-84.

Tawiah, V. K., Barnes, E. J., and Zakari, A. (2019). Does aid effectiveness differ per political ideologies? International Economic Journal, 33(2), 270-285.

Taylor, L. (1994). Gap models. Journal of Development Economics, 45(1), 17-34.

Thirlwall, A.P. (1999). Growth and development, with special reference to developing countries. London: Macmillan Press

Vasquez, I. (1998). Official assistance, economic freedom, and policy change: Is foreign aid like champagne. Cato J., 18, 275.

Weisskoff, T. E. (1972). Econometric tests of alternative constraints on economic growth of underdeveloped countries. Review of Economics and Statistics, 54, 67-78.

Young, A. T., and Sheehan, K. M. (2014). Foreign aid, institutional quality, and growth. European Journal of Political Economy, 36, 195-208. 
Appendix

\section{Appendix A: Definition, Construction of Variables under Consideration}

\begin{tabular}{|c|c|c|c|c|}
\hline Variables & Description & Definition & $\begin{array}{c}\text { Sources of } \\
\text { Variable } \\
\end{array}$ & Sources of Data \\
\hline $\begin{array}{l}\text { Dependent } \\
\text { Variable }\end{array}$ & $\begin{array}{l}\text { Economic } \\
\text { Freedom }\left(\mathrm{EF}_{\mathrm{it}}\right)\end{array}$ & $\begin{array}{l}\text { Index of } \\
\text { economic } \\
\text { freedom is; size } \\
\text { of government, } \\
\text { monetary policy } \\
\text { and price } \\
\text { stability, legal } \\
\text { structure and } \\
\text { security of } \\
\text { private property, } \\
\text { freedom to trade } \\
\text { without } \\
\text { regulations, and } \\
\text { regulation of } \\
\text { credit, labor and } \\
\text { business. It } \\
\text { ranges from 0-10. }\end{array}$ & $\begin{array}{l}\text { Gwartney et al. } \\
\text { (2015 }\end{array}$ & Fraser Institute \\
\hline $\begin{array}{l}\text { Independent } \\
\text { Variable }\end{array}$ & $\begin{array}{l}\text { Official } \\
\text { Development } \\
\text { Assistance( }\left(\mathrm{AID}_{\mathrm{it}}\right)\end{array}$ & $\begin{array}{l}\text { It is net } \\
\text { disbursement of } \\
\text { ODA received by } \\
\text { a country as a } \\
\text { fraction of gross } \\
\text { domestic } \\
\text { national income } \\
\text { with t-1 } \\
\text { representing } \\
\text { lagged one } \\
\text { period. }\end{array}$ & WDI & WDI \\
\hline $\begin{array}{l}\text { Independent } \\
\text { Variable }\end{array}$ & $\begin{array}{l}\text { Net Official } \\
\operatorname{Aid}_{\left(\text {AIDN }_{i t}\right)}\end{array}$ & $\begin{array}{l}\text { Aid flows (net of } \\
\text { repayments) } \\
\text { from official } \\
\text { donors to } \\
\text { countries and } \\
\text { territories in part } \\
\text { II of the DAC list } \\
\text { of recipients. } \\
\text { Data are in } \\
\text { current U.S. } \\
\text { dollars. }\end{array}$ & WDI & WDI \\
\hline
\end{tabular}




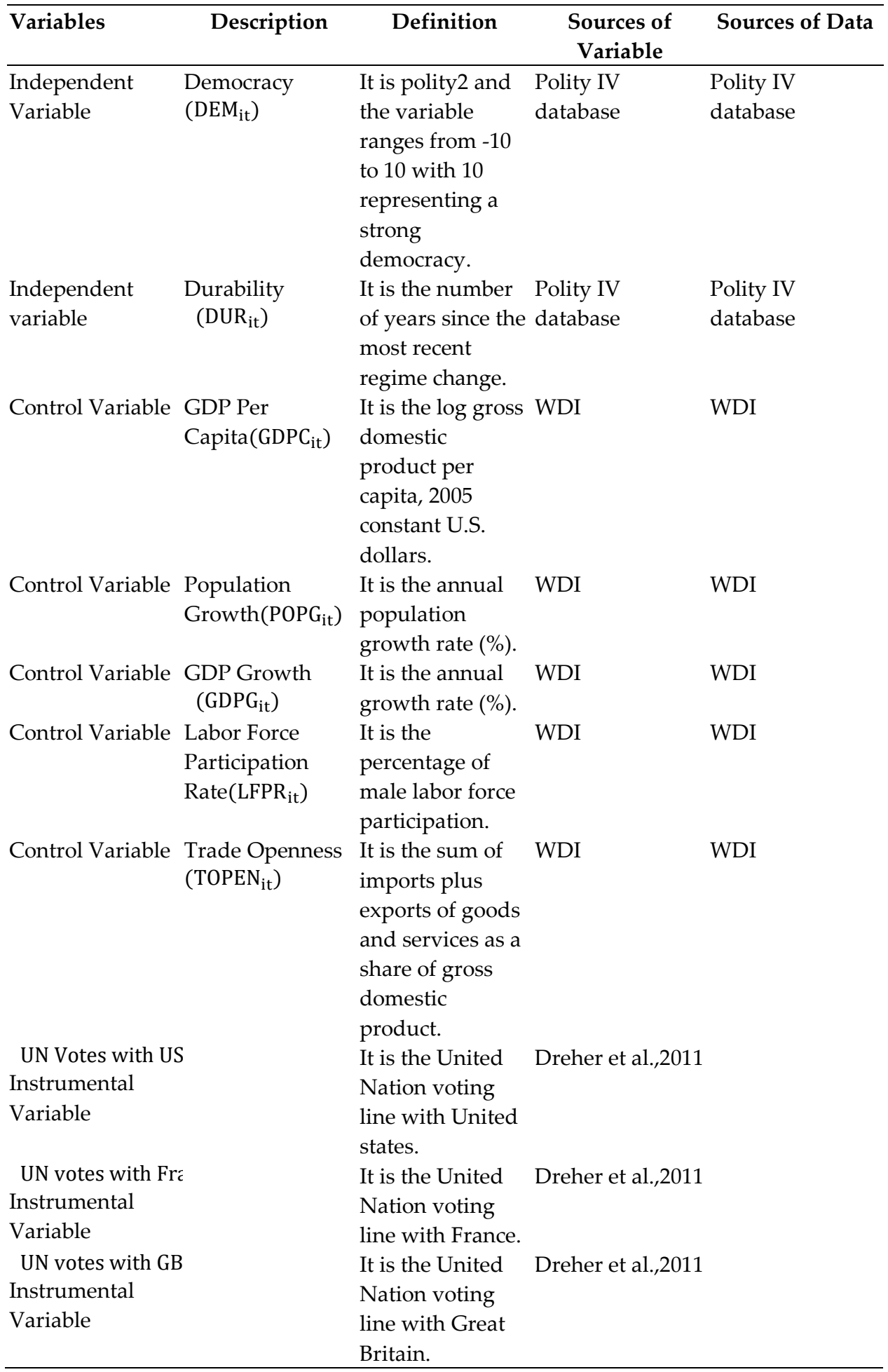




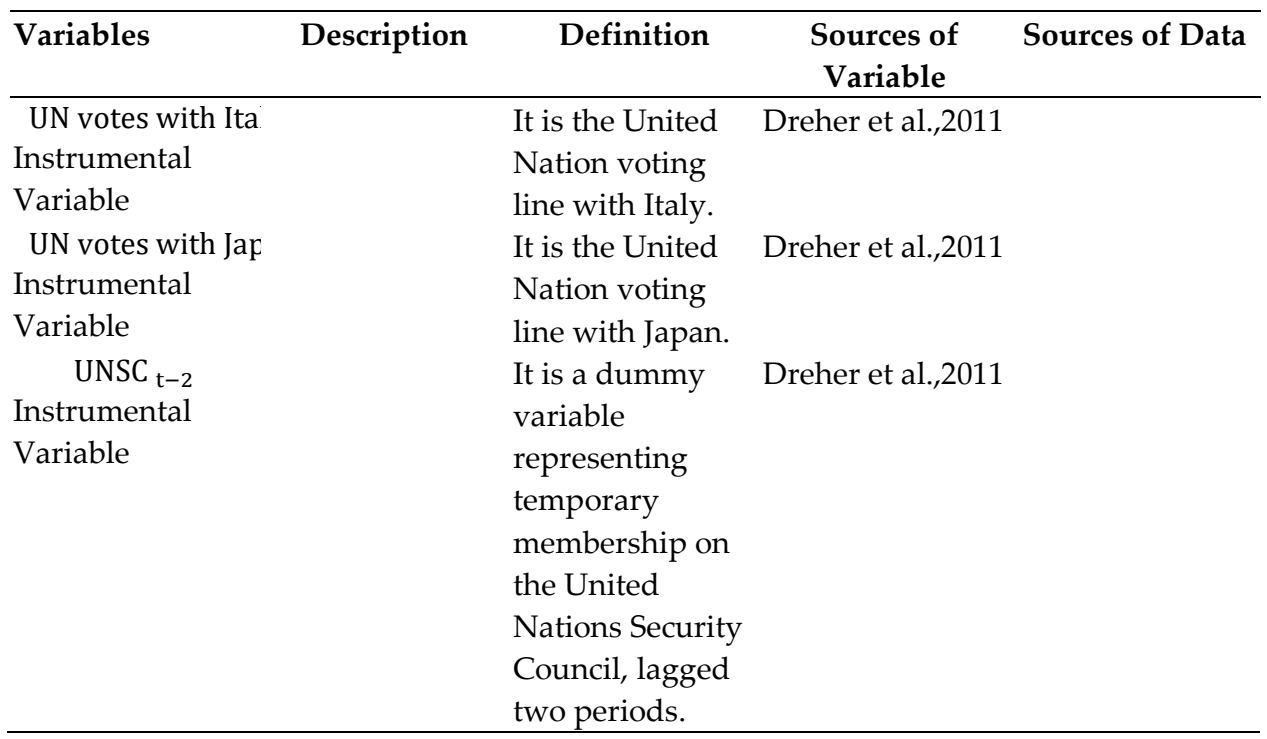

Appendix B: List of Countries under Consideration

\begin{tabular}{llllll}
\hline South Asia & East Asia & \multicolumn{2}{c}{ Latin America } & \multicolumn{2}{c}{ Sub-Sahara Africa } \\
\hline Bangladesh & Indonesia & Argentina & Guatemala & Chad & Nigeria \\
India & Malaysia & Brazil & Haiti & Ethiopia & Sierra Leo \\
Pakistan & Mongolia & Bolivia & Honduras & Ghana & Tanzania \\
Sri-Lanka & Philippine & Chile & Mauritania & Madagascar & Togo \\
& Thailand & Colombia & Panama & Malawi & Uganda \\
& Vietnam & Cost Rica & Peru & Mali & Zambia \\
& & Ecuador & Paraguay & Namibia & Zimbabwe \\
& & El Salvador & & Niger & \\
\hline
\end{tabular}

Appendix C: Bruesh and Pagan Test Results

\begin{tabular}{lcccccccc}
\hline & $\mathbf{( 1 )}$ & $\mathbf{( 2 )}$ & $\mathbf{( 3 )}$ & $\mathbf{( 4 )}$ & $\mathbf{( 5 )}$ & $\mathbf{( 6 )}$ & $\mathbf{( 7 )}$ & \multicolumn{1}{c}{$\mathbf{( 8 )}$} \\
\hline Chi $^{2}$ & 186.82 & 156.3 & 188.57 & 155.70 & 185.00 & 155.12 & 189.6 & 190.0 \\
P-Value & $(0.000)$ & $(0.000)$ & $(0.000)$ & $(0.000)$ & $(0.000)$ & $(0.000)$ & $(0.000)$ & $(0.000)$ \\
\hline
\end{tabular}

